\title{
THE IMPACT OF INFORMATION TECHNOLOGY ON ORGANIZATIONAL FLEXIBILITY
}

\author{
Henry C. Lucas, Jr. \\ Information systems Department \\ stern school of Business \\ New York University \\ Margrethe olson \\ DMR GROUP \\ victoria, Australia
}

\author{
working Paper series \\ STERN IS-93-49 \\ Replaces: IS-93-10 \\ Forthcoming: \\ Journal of Organizational Computing
}




\title{
The Impact of Information Technology on organizational Flexibility
}

\author{
by \\ Henry C. Lucas, Jr. \\ Leonard N. Stern School of Business \\ New York University \\ 44 West 4 th Street, Suite 9-67 \\ New York, NY 10012 \\ and \\ Margrethe olson \\ DMR Group \\ Level 8, South Bank Blvd. \\ Riverside Quay \\ South Melbourne, 3205 \\ Victoria, Australia
}

November 1993 


\section{THE IMPACT OF INFORMATION TECHNOLOGY \\ ON ORGANIZATIONAL FLEXIBILITY}

\section{ABSTRACT}

This paper argues that information technology can have a significant impact on organizational flexibility. Information technology (IT) contributes to flexibility by 1) changing the nature of organization boundaries and the time when work occurs 2) altering the nature and pace of work and 3) helping firms respond to changing market conditions. But, there are also aspects of technology which can decrease flexibility, and there may be second-order impacts of flexibility that are not easily predicted. Examples to illustrate the impact of information technology on two industries and three companies are presented. The paper concludes that management should consider the use of information technology to increase flexibility and suggests strategies for implementing flexible systems.

Organizational flexibility / Impact of information technology / Implementation / Second order effects 


\section{THE IMPACT OF INFORMATION TECHNOLOGY ON ORGANIZATIONAL FLEXIBILITY ${ }^{1}$}

\section{INTRODUCTION}

It has been estimated that over a third of capital expenditures in the United States are devoted to technology, but there has been little concrete evidence that this investment has improved the effectiveness of organizations. How can information technology (IT) contribute to organizational effectiveness? One measure of effectiveness is flexibility [1].

Flexibility is the ability to adapt to new or changing requirements. In a manufacturing firm, Hall [2] explained: "plants should be capable of switching quickly from one product to another, or from one part to another...almost instantly." Swamidass and Newell wrote: "Flexibility offers the capability to cope with environmental uncertainty" [3]. Severance and Passino concur: "Flexibility enables the organization to adapt to current market realities and to react appropriately as market forces change over time" [4]. "Flexibility provides the means to achieve the ends of increased growth and resource acquisition" [5] .

All of these observations suggest that flexibility is the ability to adapt when

${ }^{1}$ The authors wish to thank Professor John Turner for his comments on an earlier draft of this paper. We also thank the associate editor and anonymous referees for their extremely helpful suggestions for improving the manuscript. 
confronted with new circumstances; a flexible organization defends quickly against threats and moves rapidly to take advantage of opportunities. Flexibility provides the organization with the ability to adapt to change and respond quickly to market forces and uncertainty in its environment.

The purpose of this paper is 1) to illustrate the impact of information technology on organizational flexibility and 2) explore the implications of that impact for management.

\section{INFORMATION TECHNOLOGY}

IT refers to hardware, software, procedures, personnel, and data employed in the production, dissemination, and utilization of information, both formal and informal, in an organization [6]. While traditionally IT has included only "formal" information systems, such as reporting systems generated by a database, increasingly IT is used to facilitate informal interpersonal communication. The key technologies include computers, computer-controlled devices, and telecommunications networks; also included are electronic mail (E-mail), teleconferencing, voice mail, and facsimile transmission.

IT not only consists of tangible pieces of equipment and programs; but also represents the capacity of the organization to produce, disseminate, and digest information. IT has been used in a number of ways including 
the mechanization of information processing, the augmentation of knowledge work, and the support of coordination in the organization.

Significant IT investment is for basic mechanization of the records of production and distribution of goods and services (e.g., invoices) or for actions like themselves, electronic money transfer. Technology is also used for manufacturing (such as $C A D / C A M$ ) and computer-integrated manufacturing (CIM). A centralized database enables production and dissemination of information for management control as a by-product of mechanization.

IT also supports individual workers. Drucker [7] identified "knowledge work" as a specifically human activity, distinct from physical labor which could be automated. The notion of augmentation was first defined by Englebart [8] as "increasing the capability of a man (sic) to approach a complex problem situation, gain comprehension to suit his particular needs, and to derive solutions to problems." Today, personal computers are used widely by individuals to augment knowledge work.

IT increases the ease of connection between individuals, organizational units, and even different organizations $[9,10]$. Applications such as electronic mail, voice messaging, and facsimile transmission facilitate the communication and coordination of information required for organizational processing. Some terms used for this class 
of applications are: interpersonal computing [11], coordination technology $[12,13]$, groupware $[14]$, and computer supported groups [15].

Information Technology and Flexibility

We argue that information technology can make a major contribution to organizational flexibility. See Figure 1. < Insert Figure 1 >

We do not claim that increased flexibility has been gained, or will be gained, by every organization employing technology. Examples cited later in the paper provide evidence to support our primary contention that information technology has the potential to dramatically alter organizational flexibility.

How can IT contribute to adaptability and change? IT alters flexibility in three major ways:

1. IT can alter the time and place of work, generally by changing boundaries on where tasks are accomplished and removing constraints on when tasks are performed.

2. IT affects the nature and pace of work; most often it speeds up the processing of information. 3. IT enables the firm to respond quickly to changing market conditions.

Communications technology helps remove the constraints of time and place in decision-making [16]. Technology removes organizational boundaries by enabling easy asynchronous 
communication between different locations so that time of day and time zone are not a constraint.

Technology speeds the processing of information so that timely decisions can be made, tasks can be performed rapidly to take advantage of new opportunities, and the firm can respond to changing market conditions. Technology is the "factory" for many financial services; speed and processing power are required to provide the service or product to the customer. By using flexible manufacturing systems IT can quickly reconfigure manufacturing lines.

\section{The Flexibility Paradox}

Cameron [17] suggested that the modern corporation encounters many paradoxical situations when adapting to turbulent conditions. The difference between organizational and technological flexibility is one such paradox. Technology can contribute to organizational flexibility, but IT itself is often considered inflexible, because the technology that provides flexibility soon becomes old and hard to maintain, and the organization tends to become more inflexible over time. Many flexible systems are complex and difficult to modify. It took one airline over two years to track frequent flyer mileage in its reservations system; in the meantime, passengers had to paste a scannable label on their ticket coupon to get mileage credit for a flight.

There are many reasons that IT is complex; the simple need to interface computers and communications devices 
requires designers to confront a myriad of different interfaces and formats. Major systems include thousands, and even millions, of lines of computer code; a small error can cause major disruptions in a system. Making changes to working programs often has unanticipated consequences to some other place in the program. A complete discussion of the complexity of IT is beyond the scope of this paper, however, it seems safe to conclude that complexity reduces the flexibility of specific IT applications.

Figure 1 suggests that IT can create an unintended decrease in flexibility in two ways:

1. By increasing the time, effort, and cost to change systems; and

2. By increasing the time, effort and cost to change workflows and organization structure.

Leading organizations deal with decreases in flexibility by changes and improvements in the technology (e.g., reservations systems undergo constant technological updating and change). Hopper [18] argued that the movement toward very powerful, open systems will make it possible to implement and modify complex technology more easily in the future.

\section{Second-order Effects}

Figure 1 shows that there may be second-order effects from increasing organizational flexibility through the use of IT. These second-order effects arise primarily from 
attempts to increase flexibility, but may also be influenced by the decreased flexibility previously discussed. Secondorder effects can occur in three major areas:

1. The organization becomes more dependent on information technology.

2. The use of IT may stimulate unanticipated responses from competitors, customers, the government, and other affected individuals or groups.

3. The organization may be faced with managing greater complexity.

There is little doubt that firms have become, and are becoming, more dependent on technology. Information technology runs the airlines; they are unable to make reservations, assign seats, and load planes if their computers and communications systems are not operating properly.

An innovating firm may develop new uses of IT that offer flexibility but stimulate unanticipated responses. For example, some customers have reacted negatively to program trading by brokerage firms; after the 1987 stock market crash, one insurance company threatened to stop doing business with brokerage firms engaging in program trading. The Exchanges invented "circuit breakers" partially because flexible information technology was blamed for causing excessive price and volume movements.

If employees can work where and when they please, their 
actions can be more difficult for management to coordinate. Speeding up the pace of work can also increase stress for managers pressured for a rapid response.

\section{Outcomes}

Figure 1 indicates that flexibility, mediated by second-order effects, will lead to an outcome, either positive or negative. Most firms who use IT to increase flexibility hope to generate a positive outcome. There are examples, however, where the net outcome of positive and negative impacts is in doubt.

It should also be pointed out that the evaluation of what is positive and negative depends very much on the observer's position. The chairman of American Airlines has a much different view of the outcome of computerized reservations systems than the chairman of TWA. Individual investors may have a different view of stock Exchange trading systems than the institutional investor.

\section{Flexibility for whom?}

Information technology may increase flexibility for the customers or suppliers, as well as for the firm that developed it. Although the use of E-mail within the firm primarily benefits the organization installing the system, it also provides added flexibility to customers who use the system. But, giving customers added flexibility may reduce the supplier's flexibility since the supplier is now forced to respond more quickly to messages from the customer. In 
financial services, building more processing power provides benefits for the developer who can generate more revenue, and it provides more flexibility for the customer who can react faster.

Thus, any benefits of increased flexibility accrue to both the organization implementing the IT and related organizations and individuals like customers and suppliers. The flexibility of the implementing firm may not be increased dramatically from some applications of technology, however, the technology has increased flexibility for the industry involved. In the remainder of the paper, we discuss flexibility regardless of whether the greatest change affects the implementer or the others who interact with the implementing organization.

\section{Causality}

Any study of impacts has to deal with the question of causality. We argue that information technology has had an impact on organizational flexibility, but we cannot prove that program trading works only because of stock exchange electronic order routing systems or computer programs that scan for arbitrage opportunities. It is possible that program traders wanting to buy or sell a basket of stocks could use preprinted trading tickets delivered with great speed to floor traders. Again, the analysis of technological impacts is based on our interpretation of the literature reviewed for this paper and from personal 
experience. The reader is cautioned to consider other possible causal explanations for the data presented. Decreasing Flexibility: second-order Effects and outcomes In the following discussion, we do not specifically address instances of decreased flexibility because, given today's technology, we expect almost without exception that firms will pay a price in time, effort, and cost to change systems and workflows. The technology has not become sufficiently flexible itself, or sufficiently open, to make significant changes easy to accomplish.

We shall discuss selected second-order effects and outcomes in the examples below. In each case, not all of the second-order effects in Figure 1 are evident. For example, the kind of videoconferencing discussed for East Coast $\mathrm{Hi}$ Tech creates far less dependence on technology than does an airline reservations system.

\section{METHODOLOGY}

The remainder of this paper discusses evidence to support the model of IT and flexibility in Figure 1 . In an effort to provide the broadest possible support, evidence is drawn from two industries and three firms. Table 1 presents the source of information for each industry or company in the paper; data come from either key published reports and/or field studies. If that these data sources are consistent with the model it means only that there is 
support for model; the evidence does not prove the posited relationships posited. Other researchers might have differing interpretations of the data, and the reader is encouraged to review the sources in Table 1 to evaluate the following arguments below.

< Insert Table 1 >

\section{THE IMPACT OF IT IN THE AIRLINE INDUSTRY}

\section{stage one}

American Airlines, motivated by a need to handle increasing passenger loads and to provide better customer service $[18,19]$, developed the first fully Computerized Reservations System (CRS) in 1961 to allow the airline's agents to make reservations for passengers.

As shown in Table 2, the first stage CRS removed the boundary created by the manual reservations process.

< Insert Table 2 >

Instead of allocating seats to offices for sale, an agent had information locally on all seats available. The boundaries around the reservations process moved from a central department to each distributed agent. As reservations could be made 24 hours per day and confirmed instantaneously, the CRS created more flexibility for passengers, allowing the airline to react more quickly to market changes. The reservation systems maintained easily processed data on load factors and passenger demand; the 
airline could use these data in planning flight schedules.

\section{stage Two}

During the late 1960s and early 1970s, the airline industry, stimulated by pending de-regulation, talked of a single, cooperative reservations system that would be distributed to retail travel agents [19]. In 1976, United and American Airlines began to market their systems to travel agents.

Travel agents could now make airline reservations through a direct connection to the airline computer, without needing to contact an airline reservations staff member by telephone. In the first stage of CRS automation, the reservation process boundary was with the airline's agent; the second stage moved it to the travel agent. See Table 1.

As the systems matured, the travel agent was able to provide boarding passes as well as tickets, eliminating the need for the passenger to wait in line for a seat assignment and boarding pass at the airport. By moving part of the enplanement process from the airport to the travel agents' office, the system altered the boundaries of airport operations and speeded the boarding process for the passenger. Some agents began to offer 24 hour travel assistance for any customers who needed rerouting while on a trip.

Because it took far less time to make a reservation for a customer, retail automation altered the nature and pace of 
work for the travel agent. In addition, since all of the CRS systems include ticket printers in the agents' office, there were significant gains in agent productivity when tickets were printed by the computer rather than by hand. The stage 2 reservations systems furnished the data for yield management programs that scan the reservations database to compare future bookings with historical patterns, thus providing the ultimate in market response. The program calls attention to any price that is off the normal pace based on flight time, cities served, day of the week, and nature of the market. Then, pricing specialists can revise the price structure for the flight and/or adjust advertising to maximize the yield (revenue generated) from the flight.

For example, a reservations system might show that the Friday afternoon flight from New York to Boston has only ten reservations a week before departure. Few discount seats are made available, however, because a computer-generated history predicts that most reservations will be made on the day of departure.

The Impact of Flexibility

Over the past thirty years, the airline reservation systems have had four major impacts:

1. Better customer service.

There is no question that reservations systems make it more convenient for customers to use airlines. Travel agencies can quickly check the availability of flights and shop for lower fares for customers. Individuals 
with access to personal computers can make reservations by accessing EAASY SABRE through Compuserve or Prodigy.

2. Direct revenue generation.

It was estimated that in 1985 Sabre earned $\$ 143$ million on revenues of $\$ 336$ million and contributed more than \$2 per share to American's earnings, about one third of American's total earnings and its highest margin business $[19,20]$. When AMR Corporation (American's parent) announced it would consider bids for selling shares in Sabre, Wall Street valued the system at $\$ 1.5$ billion. At the time, AMR's market value was $\$ 2.9$ indicating that sabre had grown to slightly exceed American's core business in value [21].

\section{Less flexibility for the industry.}

These systems make it extremely expensive for non-CRS carriers to enter the CRS business. A new airline has a tremendous barrier to overcome if it wishes to enjoy the flexibility of a modern CRS. Donald Burr, founder of People Express, laid much of the blame for the demise of his airline on its inability to utilize CRS technology.

4. Transformation of the structure of the airlines and their information services organizations.

The major airlines have created subsidiaries from their reservations units. While it was a takeover target, United sold half its Covia CRS subsidiary, in which it had invested an estimated $\$ 250$ to $\$ 300$ million, to a consortium of European airlines (KLM, Swissair, and British Airways) and US Air for $\$ 500$ million. Prior to the sale, United had already agreed to form an alliance with the European airlines to develop a system for European agency automation. When Texas Air, which had entered into a similar alliance with Air France, Lufthansa, Iberia, and SAS, had problems, this second alliance turned to American Airlines for assistance in 1990. The sale of part of the American Airlines Sabre system to Delta was recently disapproved by the U.S. government which feared the power of the combined systems. American has rebounded by agreeing to develop a reservations system for Aeroflot to serve Eastern Europe. New organizational boundaries have been created (the CRS subsidiaries) and new strategic alliances formed as a result of reservations automation.

Second-order Effects and Outcomes 
Table 2 shows some of the second-order effects from airline CRS. We have already discussed the extreme technological dependence the airlines have on this and related technology for their operations. Competitors and the government have also provided unanticipated responses to these systems. The Department of Transportation has issued regulations to try and create impartiality in the systems. In August of 1992, the US Congress passed a bill to force United and American to reprogram their systems to make it as easy to book flights on other airlines as on their own. Is the net outcome from airline CRS positive or negative? From the standpoint of the CRS vendors, the systems have been extremely beneficial. A sign of their effectiveness is that competitors without the systems lodge constant complaints against their use. For the passenger, it is much easier to make reservations, and even to shop for fares. But, this advantage is offset by yield management programs that make obtaining a seat at a given price a bit of a gambling exercise.

In addition, since CRS raise barriers to entry, they reduce competition and customer power. The CRS help airlines and travel agents deal with the complexities of hub and spoke systems that require more flight segments than direct, origin-to-destination flights. A carrier with a dominant position at a hub can hold the customer hostage to high prices and possibly inferior service. 


\section{THE SECURITIES INDUSTRY}

Due to intensive information processing requirements, the securities industry, which consists of individual and institutional investors, brokerage and financial services firms and a group of exchanges, has made major investments in information systems and services.

Automation in the securities industry has focused on proprietary systems designed for a specific purpose. With the exception of the exchanges, most securities systems have had their primary impact on the firm that developed the application. Exchange applications, of course, affect all of those who use a particular exchange, e.g., national and international trading systems, such as NASDAQ (over-thecounter stocks) and Instinet (a computerized exchange owned by Reuters) [22].

\section{Back Office systems}

organizations first adopted information technology for processing large volumes of transactions. A brokerage firm must keep track of customers' accounts; the stock exchanges and clearing firms must clear all of the day's transactions. Large, back office computer systems give firms the ability to process huge volumes of transactions and meet stringent time limits.

Once a brokerage firm has information about the customer in a database, it can make that information available to a broker in a branch office to supplement the 
quotation information typically purchased from an outside vendor, such as, ADP or ILX. The technology removes boundaries on the availability of account information, which is now easily available at the broker's desk rather than from a bulky printout or through a phone call to a central processing site.

The back office systems contributed to extending the time the Exchanges can be open for trading. In the 1960s, inadequate capacity led to early closings of the New York Stock Exchange so that securities firms could catch up on transactions' processing; today systems are in place to eliminate this time constraint. The back office systems also accomplish one of their major objectives; they greatly speed the processing of customer trades.

The availability of customer information on-line meant that the broker could serve the retail customer better. The brokerage firm has become more responsive to its customers and better able to market new products and services.

\section{Trading Systems}

Faced with steadily increasing volume and concerns about their ability to complete trades in sufficient time, major exchanges have undertaken different programs of automation. The NASDAQ system provides an electronic market for over-the-counter stocks for the U.S. and several foreign countries [23]. Reuters, which handles about $30 \%$ of the world's foreign exchange transactions over its financial 
network [24], offers an electronic market in a number of stocks with its Instinet subsidiary [25].

SuperDot (Designated order Turnaround System), developed by the New York Stock Exchange to directly route orders to specialists and avoid the floor broker, is available for trades of up to 30,099 shares and limit orders of 99,999 shares [26].

The impact of information technology on flexibility of the trading process is dramatic. See Table 1. Without using a floor broker, brokers are able to route orders to the specialist on the exchange floor directly, thus removing a boundary. Electronic exchanges make it possible to eliminate an exchange floor all together.

IT enables 24-hour trading. Brokerage firms routinely "pass the book" on their foreign currency transactions from London to New York to Tokyo. A discount broker accepts phone trades all night and a computer user can submit trades at any time. The trades are not executed until an exchange opens, but that may change in future.

A computer systems' ability to process data at extremely high speeds makes it possible to offer products that could not have been considered before computerization because of the time required for computations, e.g., calculating the stock distribution in an indexed fund. These capabilities have allowed firms to open new markets and respond more effectively to their customers; the 
technology has enabled firms to develop new trading

strategies, expanding their markets.

The Impact of Flexibility

The IT-based trading systems and the flexibility they

have brought to firms in the securities industry have had

three major impacts:

1. Better customer service.

Customers have better, faster service and can even enter trades themselves through personal computers. Conceptually, there is no reason a customer should not be able to enter an order directly into the superDot system bypassing a brokerage firm entirely.

2. Possible increases in market volatility.

Has the technology unintentionally facilitated trading strategies which adversely affect liquidity and volatility? Was there insufficient processing capacity in October of 1987? Did information technology provide more constraints than it removed? On October 19,1987 one portfolio insurer sold $\$ 1.7$ billion of assets while three other firms sold over $\$ 800$ million each. Specialists and others bought $\$ 700$ million; they could not meet the liquidity demands of modern technology [27]. There has been some speculation that delays caused by insufficient systems' capacity served to buffer the October crash; trades were delayed and price discovery was almost impossible at certain times during the day [28].

3. Possible discouraging effect on individual investors

Since the crash, individual investors have largely been absent from the market [29]. The individual investor may perceive that only large firms have the technology to provide the needed information for decision making and access to various exchanges in order to trade efficiently. One unintended consequence of information technology in the securities industry may be to drive the individual investor out of the market.

\section{Second-order Effects and outcomes}

The securities industry has encountered unanticipated 
responses to its automation efforts. Certainly, the exchanges did not create systems like superDot to facilitate program trading. As mentioned earlier, the government and exchanges felt it necessary to create circuit breakers to halt trading when certain limits were exceeded on the NYSE and the Chicago markets. While systems like DOT and SuperDot were developed partially to convince small investors that their orders received the same priority as institutions, it is not clear that small investors have responded in the manner planned by the exchange.

The financial industry has faced a number of problems in managing technology. For example, brokerage firms provide brokers and traders with workstations that supply a great deal of information on the markets and customers. Managers of the major exchanges must develop technology to keep up with other exchanges and with off-exchange electronic networks. At the same time, they must be sensitive to the existing structure of their own exchange, (e.g., the presence of specialists at the New York Stock Exchange and the American Stock Exchange). At least one firm spent over two years and many millions of dollars trying to manage the development of a custom system before it terminated the project and signed an agreement to adopt a third-party broker workstation.

What is the net outcome of all of this automation? see Table 3. For securities firms, the impact has been clearly 
< Insert Table $3>$

positive; they can process more transactions with the same or fewer people. The firms have benefited greatly by trading for customers and for their own accounts using these systems.

For the individual investor, the net outcome is more difficult to determine. Systems like superDot help the small investor submit his or her order with the same or greater priority than an institution. On the other hand, the evidence suggests that small investors feel intimidated by the high volume institutional and investment company trading made possible by IT.

It is more difficult to determine the impact of IT on the market itself. There is some evidence that the technology has made a positive contribution to the quality of markets; in London after the "Big Bang," there has been higher turnover and liquidity and an increase in the depth of the market.

\section{THE IMPACT OF IT ON FLEXIBILITY IN THREE FIRMS}

The analysis in the previous sections, which presents evidence for the impact of IT on organizational flexibility in two large industries, is at a high level of generality; in this section we discuss evidence based on three specific firms' use of IT.

Discount stores 
This organization is a large retailer of a complete line of goods from clothing to food to electric appliances. The company deals with over 900 suppliers, selling nearly 80,000 products. Purchasing, which must obtain accurate sales information from hundreds of stores, deals with a fixed set of suppliers, so the task of purchasing is highly structured. The primary information exchanged is price and delivery times.

The company is experimenting with Electronic Data Interchange (EDI). A primary objective of the technology is to reduce costs through reduced error rates. Since volume of sales in stores cannot be predicted with accuracy, the company must incur inventory carrying costs or risk loss of sales because of items out of stock. The solution is to use EDI to help reduce the time for restocking.

Table 3 shows the expected impact of this technology on Discount Stores; EDI clearly reduces the organizational boundaries between Discount and its suppliers. Discount can also order at any time during the day. EDI dramatically speeds ordering and should reduce stockouts, allowing the firm to respond to customers more quickly by restocking popular items.

Table 2 suggests that Discount Stores has become much more dependent on technology as a result of its EDI efforts, and that both the store and its customers have gained. The customer should benefit from greater availability of stock, 
and the store should benefit from rapid reorders of fastmoving items and lower inventories.

Mrs. Fields' Cookies

In 1988, Mrs. Fields' Cookies, a chain of small retail outlets typically found in shopping malls and which sell several varieties of cookies and a few other selected food items, had approximately 500 retail stores world-wide. Stores follow a formula of consistent, uniform quality and price regardless of location [30, 31]. Mrs. Fields' Cookies has a unique structure: two parallel organizations, one of which has a traditional span of control and another which has a very high span.

The traditional hierarchy, formed by 500 store managers, 105 district sales managers, 17 regional directors, four senior regional directors, a vice president of operations and finally Debbi Fields, has a span of control of about $1: 5$ [32].

The second organization, a formal reporting relationship for control purposes, enables 500 store managers to report to six store controllers, who report to the vice president of operations. The span of control between store managers and controllers is 35 to 75: 1, representing a very flat organization structure. The "human" side of management at Mrs. Fields' is through a traditional hierarchy; the "numbers" side is a flat organization made possible through information technology 
$[30,32]$

Every shop is wholly-owned by the company rather than franchised, and the company is under the strong centralized control of Mrs. Fields and her husband. The unique organization of Mrs. Fields' Cookies allows the owners maximum flexibility in adapting to the changing tastes of customers in a "fad" business.

IT is an integral part of the structure of Mrs. Fields' Cookies. Each store is connected on-line to a central database, and there is extensive mechanization of production quotas, sales volumes, etc., based on recent daily sales records for each store. In fact, each store is given hourly sales projections and reports hourly sales results. All ordering of supplies (e.g., chocolate chips) is done automatically from the central database with direct delivery to the store.

Each store's product mix, sales quotas, and special promotions, are customized by an expert system that adapts to hourly sales. The company uses IT for coordination; through voice mail and electronic mail so that each store manager has direct personal interaction with Mrs. Fields herself. Company-wide announcements are frequently broadcast to each store by voice mail, significantly personalizing the announcement over memos and reports. Each manager may send Mrs. Fields electronic messages for particular problems and expect a personal response within 
forty-eight hours.

As shown in Table 1, IT has allowed Mrs. Fields' to reduce boundaries between stores and headquarters; the technology has created an organization structure that feels flat despite having many layers of management. It is also easy to communicate across time zones using voice and Email. Through detailed store operational control, the technology affects the nature and pace of work, freeing personnel for more sales work. Mrs. Fields' can be more responsive to customers; it can change products and product mix through the systems running at headquarters and in the stores.

As shown in Table 2, there have been management problems at Mrs. Fields'. Possibly encouraged by the success of its technology, the firm expanded rapidly and ran into difficulty integrating its acquisition, La Petite Boulangerie, with its traditional cookie stores [33]. While Mrs. Fields' can change its mix of cookies easily, the original cookie operation is basically a one-product business. The firm is also reported to have had difficulties with its product and market mix when it entered international markets.

The net outcome from flexible IT at Mrs. Fields' is difficult to evaluate. If the firm solves its expansion and control problems, then the net effect could be positive. If the firm must be radically restructured, or suffers a major 
reverse, and IT is believed partially responsible for the problems, then the net effect could turn out to be a negative.

\section{East coast High Tech}

This company, one of the leading US computer manufacturers and well known for its highly matrixed organizational structure, performs in a turbulent and highly competitive environment. New advances in technology frequently cause competitors to change marketing and engineering plans radically. In addition, new product development times (after research and technology transfer) are typically two to three years.

The organization structure of East coast High Tech can best be described as highly fluid. Reporting relationships change frequently and matrix relationships are common. Because of the environment and nature of the product, a structure which allows for coordination by lateral relationships across all parts of the organization (except perhaps manufacturing) is required. But, the costs of maintaining such an organization are high and, as the number of parties requiring contact increases, the needed coordination becomes highly complex and time-consuming.

One of the authors studied a sub-unit of East coast High Tech which is responsible for defining new products in a segment of the market relatively new to the company, financial services. The sub-unit defines application 
requirements based on input from industry marketing and "sells" these requirements to engineering groups for development. Similar groups in the organization compete for scarce engineering resources based on their ability to convince management of the market for a proposed product. Frequently, multiple competing products are under development in different parts of the organization. Given the structure, there is no formal mechanism for coordinating multiple activities. Product groups can take it upon themselves to form coalitions to consolidate their resources on single rather than multiple products, or to use the knowledge gained from coalitions to differentiate and justify each product.

The major IT for East Coast High Tech is an extensive data communications network connecting every part of the organization across all functions world-wide. The network is primarily used for coordination through E-mail and computer conferencing. The technology vastly increase the number of connections available to employees of the firm. Table 1 suggests that the technology at East Coast High Tech reduces geographic boundaries; a work group formed despite the physical location of the participants. The technology lets groups or individuals communicate together at one time or asynchronously. The faster communications and project completion that result from this technology should increase the firm's responsiveness to the market by reducing product 
development cycle times.

Table 2 shows that East Coast High Tech has not been completely successful in managing complex technology. In particular, it has had difficulty diffusing the success of the project team described above to other groups in the organization. No one in the firm has taken a leadership role to further develop the technology. The firm is entering a period of extreme stress, making it unlikely that what has been learned from this group will be transmitted to others.

The net effect is again hard to determine because the organization may "discover" at some point in the future the application and it will diffuse throughout the organization. An alternate scenario, most likely at this point, is that the organization has learned little from this experiment and the net effect will be neutral or negative.

\section{Impact of Flexibility}

IT has contributed to each of these firms' flexibility in different ways. The systems, and the flexibility they offer, have had an impact on each organization.

1. Discount stores.

The technology should improve operational efficiency and reduce costs. If the firm is able to restock items more quickly through EDI and increase sales, then revenues should increase. The combination of reduced costs and enhanced revenues means higher profits.

2. Mrs. Fields' Cookies.

The technology has allowed Mrs. Fields' to structure a flat organization structure for control purposes. This 
use of IT suggests how organizations may be structured in the future, substituting computer and communications for management layers and supervisory functions. The case also serves as a warning that a successful IT effort should not be used for unmanaged expansion.

3. East Coast High Tech.

This firm's approach to product development has resulted in a more fluid organization. Here the impact of the technology is to make it easier to form task forces that span organizational and physical boundaries. Although the experiment with the technology was a success, it appears that East coast High Tech may not have learned much from its efforts.

\section{DISCUSSION}

The technology deployed by the firms and industries discussed in the paper has a number of characteristics in common. Many of the applications have resulted in better customer service and more responsiveness to the market place even if that was not their original intention. Airline CRS were developed to provide customer service and to make it possible for the airlines to cope with growing reservations traffic. Brokerage firm back office systems were first developed to solve transactions' processing problems; but, the data they provided and the improvements they created in the operation of the markets also resulted in better service for the customer.

Other systems providing flexibility have concentrated on reducing cycle times. Electronic order routing systems on stock exchange, computerized markets, EDI at Discount stores, and conferencing at East coast High Tech reduce the time it takes to complete a task. Lower cycle times, in 
turn, make an organization appear more flexible to customers and allow it to explore new markets.

All of the systems offer improved access to data. These firms have often replaced paper documents with electronic data, paper becomes the second choice to displaying data on a screen. Even if the data were originally captured to improve transactions processing, the organizations described in this paper have recognized that these data, which have been made available to many employees within the firm and to external organizations through communications links, have value for other purposes.

It is interesting to note that the technology involved in most of these systems has been available for a number of years. These systems rely on on-line, fast response systems, database management, and communications networks. Changes in technology have reduced costs and increased the capabilities of computers and communications, making it feasible to apply these core technologies to developing systems that increase flexibility.

The model in Figure 1 suggests that IT can also decrease flexibility. Open systems, fourth generation languages, and database management systems all help to reduce rigidity. Few, however, would argue that it is easy to make major changes in computer and communications systems. Until such technology is available, firms will still face a paradox: systems they design to create overall 
flexibility are, themselves, often inflexible and difficult to change.

\section{IMPLICATIONS}

The evidence suggests that IT can influence organizational flexibility. Flexibility helps a firm react to the marketplace and to the actions of other firms and can contribute to competitiveness. How can organizations design systems and use technology to increase flexibility?

on an operational level, senior management must be involved in setting technology strategy, goals, and implementation, as was done by Randy and Debbie Fields and Robert Crandall at American Airlines. Applications like Email, EDI, and voice mail require senior management to take a major role in implementation. The experience of East Coast $\mathrm{Hi}$ Tech shows how a lack of leadership can substantially reduce the benefits of technology. Managers also need to be open to new ideas and the use of outside parties to build and integrate new technology [18].

One of the most difficult tasks for management is investing in building an infrastructure, like a world-wide communications network, when there may be no immediate payoff [34]. Yet, without an infrastructure, the firm is not in a position to react quickly when an opportunity arises. An infrastructure is necessary to take advantage of the flexibility offered by technology. 
Management must also be aware of the second-order effects from the application of IT to increase flexibility. Because most organizations are becoming more dependent on technology, they must ensure they have adequate staff and knowledge in the organization to implement and maintain technology. One cannot always forecast the reaction to a new technology, but management must be sensitive to unanticipated responses and be ready to deal with them. Finally, the firm must be able to manage the increased complexity that comes from the deployment of more and more information technology. In at least two of the cases, it appears that management has not been completely successful in coping with and learning from the technology.

As the IT designer also inevitably designs at least some parts of the organization, the designer of IT must consider the impact of the technology on the organization as well as on the particular task for which the technology is intended. Management should consider information technology as a major variable in the design of the organization and think about how IT can contribute to effectiveness.

Increasingly, the design of organizations will involve specifying the type of information technology the organization needs to employ. For example, Hopper [18] and Drucker [35] suggested that IT will change hierarchical organizational structures into networks of task forces and 
problem solvers. Technology can contribute to creating the organizational structure desired by management, and in some cases technology may be what makes a particular structure possible.

One theme for the 1990s is competitiveness;

organizational flexibility can contribute to competitiveness by helping the organization react more quickly to the marketplace and take advantage of new opportunities. one challenge for management in the $1990 \mathrm{~s}$ is to take advantage of information technology to increase organizational flexibility. 


\section{REFERENCES}

[1] J. P. Campbell, "On the nature of organizational effectiveness," in New Perspectives on Organizational Effectiveness, P. S. Goodman and J. M. Pennings, Eds. San Francisco: Jossey-Bass, 1977, pp. 13-55.

[2] R. W. Hall, Zero Inventories. Homewood, IL: Dow JonesIrwin, 1983 .

[3] P. M. Swamidass and W. T. Newell, "Manufacturing strategy, environmental uncertainty and performance: A path analytic model," Management Science, vol. 33, no. 4, pp. 509-524, April 1987.

[4] D. Severance and J. Passino, "Sainthood for U.S. manufacturing? More managers are talking about heaven than going there," Planning Review, pp. 4-11, 27, NovemberDecember, 1988 .

[5] Quinn, R. E. and J. Rohrbaugh, "A spatial model of effectiveness criteria: Toward a competing values approach to organizational analysis," Management Science, vol. 29, no. 3, pp. 363-377, March 1983. 
[6] Gordon B. Davis and Margrethe H. Olson, Management Information Systems: Conceptual Foundations, Structure, and Development, second edition. New York: McGraw-Hill, 1985.

[7] Peter Drucker, Managing for Results. London: Pan Books, Ltd. , 1964 .

[8] Douglas Englebart, "A conceptual framework for the augmentation of man's intellect", Vistas in Information Handling, 1963 .

[9] Peter Drucker, "The coming of the new organization", Harvard Business Review, pp. 45-53, January-February 1988.

[10] Thomas W. Malone, J. Yates, and R. I. Benjamin, "Electronic markets and electronic hierarchies", Communications of the ACM, vol. 30, pp. 484-497, 1987.

[11] Adele Goldberg, Internal Report, Xerox Palo Alto Research Corporation, 1987.

[12] Anatole Holt, "Diplans: A new language for the study and implementation of coordination", ACM Transactions on office Information Systems, vol. 6, no. 3, pp. 109-125, April 1988. 
[13] Thomas W. Malone, "What is coordination theory?", MIT SSM WP 2051-88, Massachusetts Institute of Technology, February 1988 .

[14] Louis S. Richman, "Software catches the team spirit," Fortune, pp. 125-136 (a), June 8, 1987.

[15] Robert Johansen, Computer supported Groups, New York: Free Press, 1988 .

[16] Joshua, Meyrowitz, No Sense of Place: The Impact of Electronic Media on Social Behavior, New York: Oxford University Press, 1985.

[17] K. Cameron, "Effectiveness as paradox: Consensus and conflict in conceptions of organizational effectiveness," Management Science, vol. 32, no. 5, pp. 539-553, May 1986.

[18] M. Hopper, "Rattling SABRE - new ways to compete on information," Harvard Business Review, pp. 118-125, May-June 1990.

[19] D. Copeland and J. McKenney, "Airline reservations systems: Lessons from history," MIS Quarterly, vol. 12, no. 3, pp. 353-370, September 1988 . 
[20] Forbes, December 30, 1985.

[21] E. Clemons and B. Weber, "Strategic IT investments," JMIS, vol. 7, no. 2, pp. 9-28, Fall 1990.

[22] H. C. Lucas, Jr. and R. A. Schwartz, Eds., The challenge of Information Technology for the Securities Markets, Homewood, IL: Dow-Jones Irwin, 1989.

[23] John Wall, "Formal links among exchanges," in The Challenge of Information Technology for the Securities Markets, H. C. Lucas, Jr. and R. A. Schwartz, Eds., Homewood, IL: Dow-Jones Irwin, 1989.

[24] E. Clemons and J. Adams, "Global competition in corporate capital markets," in The challenge of Information Technology for the Securities Markets, H. C. Lucas, Jr. and R. A. Schwartz, Eds., Homewood, IL: Dow-Jones Irwin, 1989.

[25] Reuters Holdings, PLC. Case 188-107, Boston: Harvard Graduate School of Business Administration, 1988 .

[26] A. Allen and L. Zarembo, "The display book: The NYSE specialist's electronic workstation," in The challenge of Information Technology for the Securities Markets, H. C. Lucas, Jr. and R. A. Schwartz, Eds., Homewood, IL: Dow-Jones 
Irwin, 1989.

[27] Robert Wood, "Survival strategies for exchanges," in The Challenge of Information Technology for the Securities Markets, H. C. Lucas, Jr. and R. A. Schwartz, Eds., Homewood, IL: Dow-Jones Irwin, 1989.

[28] New York Times, October 16, 1988.

[29] Arthur Leavitt, "The view from the american stock exchange," in The Challenge of Information Technology for the Securities Markets, H. C. Lucas, Jr. and R. A. Schwartz, Eds., Homewood, IL: Dow-Jones Irwin, 1989.

[30] "Mrs. Fields' Cookies," Harvard Business School Case, No. 9-189-056, 1988 .

[31] Tom Richman, "Mrs. Fields' secret ingredient," Inc. Magazine, 65-72 (b), October, 1987.

[32] "Mrs. Fields' cookies teaching note," Harvard Business School Case, No. 5-193-035, 1992.

[33] Wall Street Journal, January 26, 1989.

[34] D. Vincent, The Information-Based Corporation. 
Homewood, IL: Dow Jones-Irwin, 1990.

[35] Peter Drucker, "The coming of the new organization," Harvard Business Review, pp. 45-53, January-February 1988. 


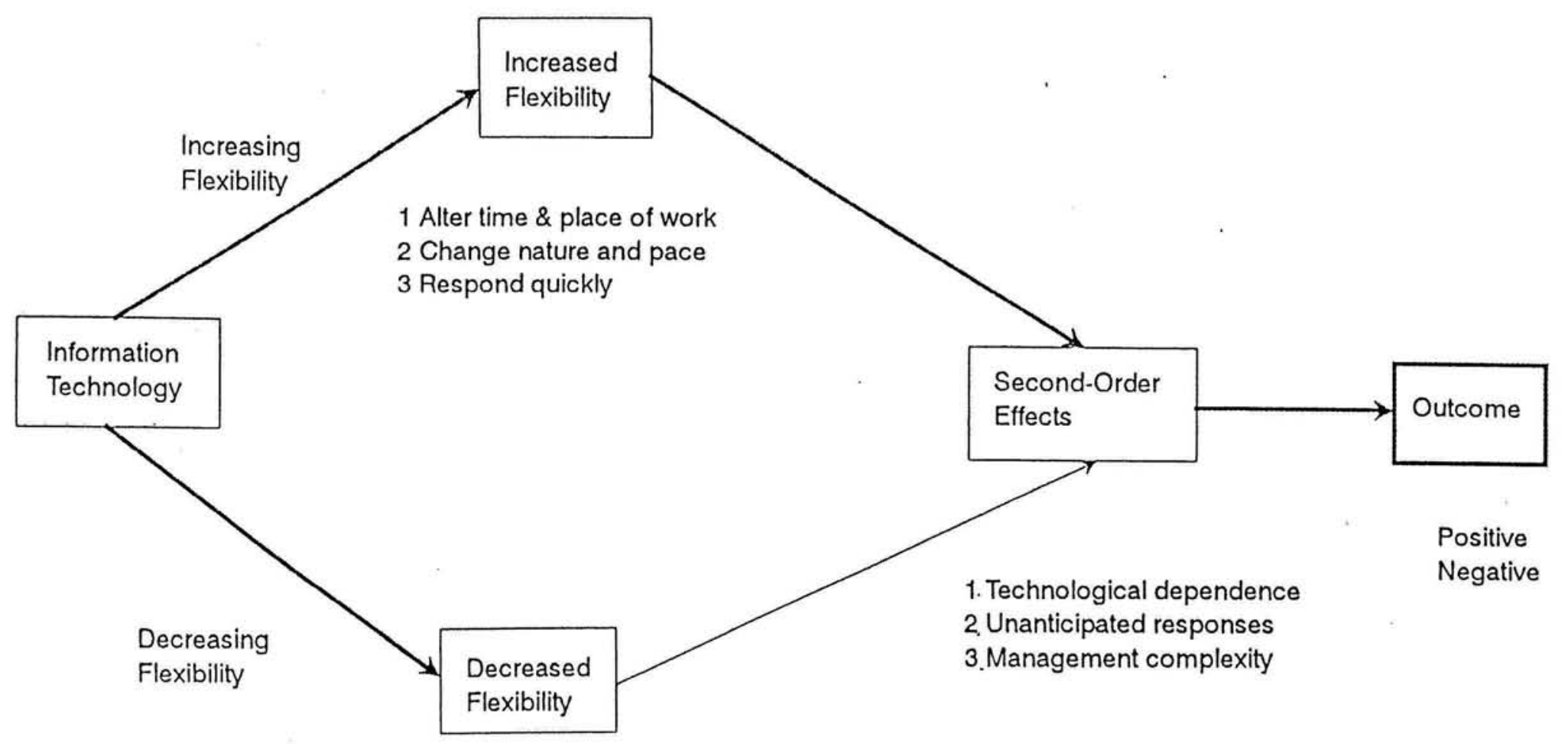

1. Increase time, effort, cost

to change systems

2. Increase time, effort, cost

to change work flows \&

organization structures

\author{
Information Technology \& \\ Organizational Flexibility Model \\ Figure 1
}


Organization and system

\begin{tabular}{|l|}
\hline Airline CRS \\
\hline Securities firms and industry \\
\hline Discount Stores EDI \\
Mrs. Fields Cookies: E-mail, voice \\
mail and store control
\end{tabular}

East Coast High Tech

teleconferencing
Key Sources of Data

Copeland and McKenney 1988 (6)

Hopper, 1990 (18)

Diverse news stories

Lucas and Schwartz, 1989 (22, 23)

Allen and Zarembo, 1989 (1)

Wood 1989 (40)

Reuters Case $1988 \quad(29)$

Field research

Harvard Case, 1989 (12)

Harvard Note, 1992 (13)

Richman, 1987 (31)

Field research

Data Sources

Table 1 


\begin{tabular}{|c|c|c|c|c|}
\hline Organization & Boundaries & Time & $\begin{array}{l}\text { Nature \& Pace } \\
\text { of Work }\end{array}$ & $\begin{array}{l}\text { Responsiveness } \\
\text { to Market }\end{array}$ \\
\hline Airline CRS Stage 1 & $\begin{array}{l}\text { Remove boundary of } \\
\text { manual centralized } \\
\text { processing; make } \\
\text { reservation any } \\
\text { place }\end{array}$ & $\begin{array}{l}\text { Make reservations any } \\
\text { time }\end{array}$ & $\begin{array}{l}\text { Confirmed reservations } \\
\text { made instantaneously }\end{array}$ & $\begin{array}{l}\text { Alter schedules } \\
\text { in response to loads }\end{array}$ \\
\hline Airline CRS Stage 2 & $\begin{array}{l}\text { Boundary for making } \\
\text { reservation shifts to } \\
\text { agent from airline; } \\
\text { airport boarding pass } \\
\text { moved to travel } \\
\text { agency }\end{array}$ & $\begin{array}{l}\text { Extra service by } \\
\text { agent, e.g., } 24 \text {-hour } \\
\text { assistance }\end{array}$ & $\begin{array}{l}\text { Travel agent becomes } \\
\text { more productive }\end{array}$ & $\begin{array}{l}\text { Yield management } \\
\text { programs allow } \\
\text { instantaneous } \\
\text { adjustment to demand } \\
\text { for seats }\end{array}$ \\
\hline $\begin{array}{l}\text { Securities firm back } \\
\text { office }\end{array}$ & $\begin{array}{l}\text { Make data available } \\
\text { to brokers on-line }\end{array}$ & $\begin{array}{l}\text { Eliminate need to } \\
\text { close exchanges early }\end{array}$ & $\begin{array}{l}\text { Greatly speed } \\
\text { processing of trades }\end{array}$ & $\begin{array}{l}\text { Create new products } \\
\text { and services }\end{array}$ \\
\hline $\begin{array}{l}\text { Securities industry } \\
\text { trading at exchanges } \\
\text { and member firms }\end{array}$ & $\begin{array}{l}\text { Able to route orders } \\
\text { without intervention } \\
\text { of floor broker; } \\
\text { floor becomes an } \\
\text { extension of } \\
\text { brokerage office; } \\
\text { may remove need for } \\
\text { floor, e.g. NASDAQ, } \\
\text { London Stock Exchange }\end{array}$ & $\begin{array}{l}\text { Movement toward } 24- \\
\text { hour trading; passing } \\
\text { the book around the } \\
\text { world for currency: } \\
\text { NYC to London to } \\
\text { Tokyo; trade any time }\end{array}$ & $\begin{array}{l}\text { Able to execute trading } \\
\text { decisions } \\
\text { instantaneously }\end{array}$ & $\begin{array}{l}\text { Enable new investment } \\
\text { strategies }\end{array}$ \\
\hline Discount Stores EDI & $\begin{array}{l}\text { Reduce boundary with } \\
\text { suppliers }\end{array}$ & Order at any time. & $\begin{array}{l}\text { Increase speed of } \\
\text { ordering; reduce } \\
\text { stockouts }\end{array}$ & $\begin{array}{l}\text { Respond quickly to } \\
\text { customer demand }\end{array}$ \\
\hline $\begin{array}{l}\text { Mrs. Fields Cookies: } \\
\text { E-mail, voice mail } \\
\text { and store control }\end{array}$ & $\begin{array}{l}\text { Bring stores closer } \\
\text { to headquarters; } \\
\text { create flat structure } \\
\text { for control }\end{array}$ & $\begin{array}{l}\text { Communicate across } \\
\text { time zones }\end{array}$ & $\begin{array}{l}\text { Automate micro-level } \\
\text { management of store; } \\
\text { free personnel for } \\
\text { sales }\end{array}$ & $\begin{array}{l}\text { Change product mix } \\
\text { and composition in } \\
\text { entire chain hourly } \\
\text { based on demand }\end{array}$ \\
\hline $\begin{array}{l}\text { East Coast High Tech } \\
\text { teleconferencing }\end{array}$ & $\begin{array}{l}\text { Reduce geographic } \\
\text { boundaries }\end{array}$ & $\begin{array}{l}\text { Communicate as a } \\
\text { group or } \\
\text { asynchronously }\end{array}$ & $\begin{array}{l}\text { Faster communications } \\
\text { and project completion }\end{array}$ & $\begin{array}{l}\text { Potential to reduce } \\
\text { product development } \\
\text { cycle times }\end{array}$ \\
\hline
\end{tabular}

Organizational Flexibility in

Two Industries and Three Firms

Table 2 


\begin{tabular}{|c|c|c|}
\hline Organization & Second-Order Effects & Outcome \\
\hline CRS & $\begin{array}{l}\text { Technological Dependence: } \\
\text { Depend totally on highly } \\
\text { centralized computer and } \\
\text { communications network } \\
\text { Unanticipated Response: } \\
\text { Government regulation }\end{array}$ & $\begin{array}{l}\text { CRS Vendor: } \\
\text { Extremely positive } \\
\text { Passenger: } \\
\text { Mixed;- greater convenience, victim } \\
\text { of yield management, hub systems } \\
\text { Airline Non-CRS Vendor: } \\
\text { Extremely negative; barriers to } \\
\text { entry }\end{array}$ \\
\hline Securities Industry & $\begin{array}{l}\text { Unanticipated Response: } \\
\text { Government and investor concerns } \\
\text { Management Complexity: } \\
\text { Managing rapidly changing } \\
\text { technology; coping with large } \\
\text { number of institutions and } \\
\text { constituents }\end{array}$ & $\begin{array}{l}\text { Securities Firms: } \\
\text { Positive-trading profits } \\
\text { Exchanges: } \\
\text { Positive-maintain market share } \\
\text { Individual Investor: } \\
\text { Mixed-faster service, but } \\
\text { intimidated by large firms }\end{array}$ \\
\hline Discount Stores & $\begin{array}{l}\text { Technological Dependence: } \\
\text { Much more dependent after EDI }\end{array}$ & $\begin{array}{l}\text { Customers: } \\
\text { Positive-better stocked } \\
\text { Firm: } \\
\text { Positive-efficiency }\end{array}$ \\
\hline Mrs. Fields' Cookies & $\begin{array}{l}\text { Management Complexity: } \\
\text { Encouraged expansion beyond } \\
\text { ability to manage }\end{array}$ & $\begin{array}{l}\text { Firm: } \\
\text { Net positive if control restored }\end{array}$ \\
\hline East Coast High Tech & $\begin{array}{l}\text { Management Complexity: } \\
\text { Learn from experience and diffuse } \\
\text { the innovation }\end{array}$ & $\begin{array}{l}\text { Firm: } \\
\text { Net negative? Little } \\
\text { organizational learning }\end{array}$ \\
\hline
\end{tabular}

Second-Order Effects and Outcomes From Using IT

Table 3 